\title{
Equal Opportunity and School Financing: Towards a Moral Theory of Constitutional Adjudication*
}

\author{
David A. J. Richards†
}

At the conclusion of a recent article, Professor Ronald Dworkin spoke in general terms of "a fusion of constitutional law and moral theory, a connection that, incredibly, has yet to take place." 1 This article adopts Dworkin's general thesis that "[c]onstitutional law can make no genuine advance" until such a fusion becomes a reality ${ }^{2}$ and tries to indicate, by critical examination of one constitutional problem, how this fusion might be accomplished.

It seems generally implausible to hypothesize a necessary logical relation between concepts of law or a legal system and substantive moral values. Yet to suppose some type of necessary relation in American legal experience is not similarly implausible. In America we have written state and federal constitutions that literally incorporate substantive moral criteria into conditions of legal validity. For example, the fourteenth amendment speaks of "due process of law" and "equal protection of the laws." Such language approaches requiring that, to constitute valid law, governmental enactments or actions must give all people their moral due or treat them equally as persons. Of course, this statement is a rather inexact expression of a more complex truth; ${ }^{3}$ it is clear that constitutionally valid state laws can be substantively immoral $^{4}$ and that laws can be moral yet constitutionally invalid. ${ }^{5}$

- An earlier version of this paper was read to the Tuesday Evening Club, affliated with the Conference for the Study of Political Thought, at Rockefeller University on May 8, 1973. This article has also profited greatly from the criticisms and assistance of John B. Moore, Richard Parker, Peter Williams, Kenneth Winston, Joshua Rabinowitz, Jeffrey Blustein, Garroll D. Grant, Henry Fields, Laurent Alpert, and Christopher Norall.

$\uparrow$ Member, New York State Bar.

1 Dworkin, Nixon's Jurisprudence, THE New York Review of Books, May 4, 1972, at 35. See also Dworkin, Legal Research, DaEDalus, Spring, 1973, at 63.

2 Dworkin, Nixon's Jurisprudence, supra note 1, at $\mathbf{3 5}$.

3 A more accurate formulation of the conditions of legal validity in the United States would include some notion that due process and equal protection are defined by decisions of the Supreme Court, leaving open the possibility of a gap between moral and legal justification.

4 For example, statutes regulating sexual conduct between consenting adults. See Baker v. Nelson, 291 Minn. 310, 191 N.W.2d 185 (1971), appeal dismissed, 409 U.S. 810 (1972).

5 See A.L.A. Schechter Poultry Corp. v. United States, 295 U.S. 495 (1935). 
Moral ideas undeniably play a significant role, however, in the interpretation and application of general constitutional clauses. For example, Supreme Court decisions on racial desegregation ${ }^{6}$ and political reapportionment ${ }^{7}$ have reflected shifts in moral thought that dictated legal shifts. The connection between law and morals in the United States is more than would be required by the mere concepts of law and morality; the moral conscience of the American polity is critically involved in interpreting the due process and equal protection clauses. Such interpretations either express widely held moral attitudes or guide moral attitudes towards an enlightened morality worth urging or imposing on others.

This article examines the moral theory embodied in adjudications under the equal protection clause: more specifically, the adjudications that claim to employ the "strict" as opposed to the "weak" standard of equal protection review. The focus of concern is the recent school financing decision, San Antonio Independent School District v. Rodriguez, ${ }^{8}$ in which the Supreme Court refused to employ the strict standard. This decision poses major questions regarding the moral analysis of constitutional values and thus is useful for the general purposes of the present analysis.

This article tries to show that there is a theory of political morality that can fundamentally illuminate the legal and moral problem of constitutional adjudication in the United States, as well as cognate issues of legislative reform. Thus, the consideration of only one Supreme Court decision must be understood as the specific application of both a more general method and a more comprehensive theory to which this article is merely a preface. The examination will include a brief summary of the standards of review under the equal protection clause, a discussion of the general trend of school financing decisions in relation to these standards, ${ }^{9}$ and a description of how Rodriguez applied these standards. ${ }^{10}$ This article then formulates the principles of justice that should apply in equal protection cases, ${ }^{11}$ criticizes the majority opinion in Rodriguez through legal and moral analysis, ${ }^{12}$ and discusses the proper direction of legislative reform. ${ }^{13}$

6 E.g., Brown v. Board of Educ., 347 U.S. 483 (1954).

7 E.g., Reynolds v. Sims, 377 U.S. 533 (1964); Baker v. Carr, 369 U.S. 186 (1962).

8411 U.S. 1 (1973).

- See text and notes at notes 14-36 infra.

10 See text and notes at notes 37-54 infra.

11 See text and notes at notes 55-119 infra.

12 See text and notes at notes 120-39 infra.

13 See text and notes at notes 140-57 infra. 


\section{The Constitutional Ghallenge to Public School Financing}

\section{A. The Standards of Review}

The fourteenth amendment provides that "[n]o State shall ... deny to any person the equal protection of the laws." This amendment was motivated by the post-Civil War desire to provide firm and undeniable constitutional guarantees for the congressional enactments effecting the abolition of slavery and concomitant state practices. The language of the amendment is, however, far broader than the original slavery concerns, leading the courts, under the guidance of the Supreme Court, to attempt to enunciate broader standards by which equal protection of the laws is to be judged. ${ }^{14}$

This development has taken the form of two different standards of equal protection review. The strict standard of review, or "strict scrutiny" test, is used where the court finds that a legislative classification is "suspect" or involves certain "fundamental interests," such as voting rights, ${ }^{15}$ access to the criminal process, ${ }^{16}$ freedom from racial injustice, ${ }^{17}$ the right to travel, ${ }^{18}$ and the right to procreate. ${ }^{18}$ A legislative scheme that classifies people unequally relative to such fundamental interests is valid only if it can be shown that the legislative

14 An excellent account of this development is presented in Developments in the Law -Equal Protection, 82 HARv. L. Rev. 1065 (1969).

15 E.g., Harper v. Virginia Bd. of Elections, 383 U.S. 663 (1966) (Virginia poll tax held unconstitutional). See also Reynolds v. Sims, 377 U.S. 533 (1964); Baker v. Carr, 369 U.S. 186 (1962).

16 Douglas v. California, 372 U.S. 353 (1963) (denial to an indigent of counsel on appeal held unconstitutional); Gideon v. Wainwright, 372 U.S. 335 (1963) (denial to an indigent of counsel in a criminal case held unconstitutional); Griffin v. Illinois, 351 U.S. 12 (1956) (failure to provide stenographic transcript on appeal to defendant unable to afford it held unconstitutional).

17 The Supreme Court cases finding racial discrimination a ground for strict scrutiny review stretch from Strauder v. West Virginia, 100 U.S. 303 (1880) (statutory exclusion of Blacks from juries invalidated) to Loving v. Virginia, 388 U.S. 1 (1967) (prohibition of miscegenation invalidated).

18 E.g., Shapiro v. Thompson, 394 U.S. 618 (1969) (statutory provisions denying welfare assistance to persons who met all eligibility requirements except that they had not resided within the jurisdiction for at least a year immediately preceding their applications for assistance held unconstitutional). A similar issue is raised by the line of cases that apply the strict scrutiny test to classifications based on alienage. E.g., In re Griffiths, 93 S. Ct. 2851 (1973) (Connecticut's exclusion of aliens from the bar held unconstitutional); Sugarman v. Dougall, 93 S. Ct. 2842 (1973) (New York statute forbidding non-citizens from being in New York civil service held unconstitutional).

19 E.g., Skinner v. Oklahoma $e x$ rel. Williamson, 316 U.S. 535, 541 (1942) (Oklahoma statute providing for compulsory sterilization of habitual criminals held subject to strict scrutiny, because it affected "one of the basic civil rights"). For a related decision under the due process clause, see Roe v. Wade, 410 U.S. 113 (1973) (Texas abortion statute held unconstitutional as infringing on the right to privacy and the liberty not to have children). 
scheme is necessary to advance a compelling state interest and that it is the alternative least restrictive of the fundamental interests involved. ${ }^{20}$ This standard is in contrast to the "weak" standard of equal protection review, covering all other cases, under which it suffices that the method of classification has some rational basis. ${ }^{21}$

\section{B. Standards in School Financing Cases}

The allegedly discriminatory pattern of public elementary and high school financing in most states has prompted litigation based on a proposed extension of the strict scrutiny standard. The general pattern of such financing involves, as a central feature, delegation by the state to local school districts of the power to finance education through local property taxes. Local school districts within the states generally contain diverse amounts of taxable property, not necessarily varying in proportion to population, and their ability to raise revenue for education differs accordingly. ${ }^{22}$

Based on the Supreme Court's expanding use of strict review in cases involving voting rights, interstate travel, and indigent criminal defendent cases, some commentators suggested that the typical pattern of educational financing would be a reasonable next target for such review. ${ }^{23}$ This general attempt to develop a constitutional attack on

20 This standard almost always results in the action being held unconstitutional.

21 E.g., Morey v. Doud, 354 U.S. 457 (1957) (statute regulating currency exchanges, except the American Express Company, held unconstitutional); Railway Express Agency v. New York, 336 U.S. 106 (1949) (statute prohibiting vehicles from carrying advertising on their sides, except self-advertising, held constitutional). This standard almost always results in the action being found constitutional. Morey v. Doud, supra, is the most frequently cited exception.

22 For example, District $A$ may have $\$ 1,000,000$ of assessable property per capita, while District $B$ has $\$ 100,000$. As a result, $A$ can raise $\$ 10,000$ for its schools with a one percent tax rate; but $B$ could raise this amount only by imposing an unusually high rate of ten percent. In San Antonio Indep. School Dist. v. Rodriguez, 411 U.S. 1, 12 (1973), the Supreme Court noted that a tax rate of $\$ 1.05$ per $\$ 100$ of taxable property was the highest rate in the San Antonio metropolitan area. The ultimate consequence of this system of financing is that property-rich districts raise more revenue for education than propertypoor districts.

23 See, e.g., A. WISE, RICH Schoors POOR Schoors (1968); Horowitz, Unseparate But Unequal-The Emerging Fourteenth Amendment Issue in Public School Education, 13 U.C.L.A.L. REv. 1147 (1966). For a statement of the opposing proposition, see Kurland, Equal Educational Opportunity: The Limits of Constitutional Jurisprudence Undefined, 35 U. CHI. L. REv. 583 (1968).

The most influential argument was developed in J. Coons, W. Clune \& S. Sugarman, Private Wealth and Public Education (1970) [hereinfater cited as Coons, Clune \& SugArMAN]. The authors suggested that, as a constitutional test, expenditures on education may not be a function of wealth other than wealth of the state as a whole. Id. at $303 \mathrm{ff}$. They also suggested a standard of legislative reform. Id. at 201-42. More important, they maintained that public elementary and high school education should be deemed a funda- 
the validity of school financing was initially not well received by courts. Thus, in 1969, three judge district courts twice rejected claims of unconstitutionality made against school financing systems that heavily depended on local property taxes and consequently involved significant disparities in local districts' school expenditures; ${ }^{24}$ these decisions were summarily affirmed by the Supreme Court. ${ }^{25}$

In Serrano v. Priest, ${ }^{26}$ however, the California Supreme Court held that the California system of school financing violated the equal protection clause of the fourteenth amendment and comparable provisions in the California constitution. ${ }^{27}$ The court found education to be a constitutionally protected fundamental interest ${ }^{28}$ and, applying the strict scrutiny test, held that the California method of local district school financing affected this interest in a discriminatory way that did not advance any compelling state interest. ${ }^{29}$ The court admitted that creating local control of some aspects of education (for example, curricula or hiring) may be a compelling state interest, but found that the financing system was not necessary to further this interest. ${ }^{30}$ In addition, the court refused to consider whether creating local control of amounts of educational expenditures was a compelling interest, because, given disparities among districts in available taxable wealth, the claim that the California system afforded such an opportunity was "a cruel illusion." 31

The decision in Serrano was followed by an explosion of state and federal cases holding similar methods of state educational financing unconstitutional under either the equal protection clause ${ }^{32}$ or provi-

mental interest subject to the strict scrutiny standard and that the typical pattern of financing was thus unconstitutional. Id. at 339-433. A more concise statement of their position was presented in Coons, Clune \& Sugarman, Educational Opportunity: A Workable Constitutional Test for State Financial Structures, 57 CALIF. L. REv. 305 (1969) [hereinafter cited as Coons, Clune \& Sugarman, Educational Opportunity].

24 Burruss v. Wilkerson, 310 F. Supp. 572 (W.D. Va. 1969), aff'd, 397 U.S. 44 (1970); McInnis v. Shapiro, 293 F. Supp. 327 (N.D. Ill. 1969).

25 Burruss v. Wilkerson, 397 U.S. 44 (1970); McInnis v. Ogilvie, 394 U.S. 322 (1969). The force of these summary affirmances was minimized in CoONs, CuUne \& SUgarman, supra note 23, at 305-15, and Serrano v. Priest, 5 Cal. 3d 584, 615-18, 487 P.2d 1241, 96 Cal. Rptr. 601 (1971).

265 Cal. 3d 584, 487 P.2d 1241, 96 Cal. Rptr. 601 (1971).

27 Id. at 598, 487 P.2d at 1250, 96 Cal. Rptr. at 610; see id. at $596 \mathrm{n} .11,487$ P.2d at 1249 n.11, 96 Cal. Rptr. at 609 n.11.

28 Id. at 604-10, 487 P.2d at 1255-59, 96 Cal. Rptr. at 615-19.

29 Id. at 610-15, 487 P.2d at 1259-63, 96 Cal. Rptr. at 619-23.

80 Id. at 610-11, 487 P.2d at 1259-60, 96 Cal. Rptr. at 619-20.

$31 \mathrm{Id}$. at 611,487 P.2d at 1260, $96 \mathrm{Cal}$. Rptr. at 620.

82 E.g., Rodriguez v. San Antonio Indep. School Dist., 337 F. Supp. 280 (W.D. Tex. 1971); Van Dusartz v. Hatfield, 334 F. Supp. 870 (D. Minn. 1971). 
sions of the applicable state constitution. ${ }^{33}$ Since the California Supreme Court remanded the case for factual determinations, Serrano was nonfinal and therefore not directly appealable to the United States Supreme Court. ${ }^{34}$ It was not long, however, before San Antonio Independent School District v. Rodriguez ${ }^{35}$ presented the Court with the question of whether the system of educational financing in Texas, and by implication in forty-eight other states, ${ }^{36}$ violated the equal protection clause of the fourteenth amendment.

\section{The Rodriguez CASE}

\section{A. The Majority Opinion}

The Texas system of school financing considered in Rodriguez is similar to the system presented in Serrano in that it results in substantial local financing of educational expenditures. ${ }^{37}$ The Supreme Gourt,

33 E.g., Robinson v. Cahill, 62 N.J. 473, 303 A.2d 273 (1973) (financing system held unconstitutional under the New Jersey Constitution's requirement of "the maintenance and support of a thorough and efficient system of free public schools," but not under the fourteenth amendment's equal protection clause); Milliken v. Green, 389 Mich. 1, 203 N.W.2d 457 (1972) (system of school financing held unconstitutional under the equal protection clause of the Michigan Constitution; the Michigan Constitution also imposed a property tax rate limitation effectively preventing property-poor districts from using rates that might raise revenues comparable to property-rich districts).

3428 U.S.C. $\$ 1257$ (1970). The decision may also have been unreviewable as being based on independent state grounds. See Karst, Serrano v. Priest: A State Court's Responsibilities and Opportunities in the Development of Federal Constitutional Law, 60 GALr. L. REv. $720,743-48$ (1972).

35411 U.S. 1 (1973).

30 Hawaii, with a system of centralized school financing, is the only exception.

37 The financing of public elementary and secondary schools in Texas is a product of state and local participation and consists of two parts. First, there is the Texas Minimum Foundation School Program in which the state supplies, out of general tax revenues, approximately 80 percent of the Program funds and the school districts, as a unit, provide the remaining 20 percent. The districts' share is divided among 254 counties pursuant to an economic index that takes into account the contribution of each county to Texas's total income from manufacturing, mining, and agricultural activities; the relative share of payrolls paid within the state; and, to a lesser extent, the portion of the state's total property in each county. The distribution of the funds raised under the Foundation Program is made according to standards intended to insure that a minimum level of education expenditures is possible in each district. (The Texas constitution also mandates a per child grant, but this grant is less than and deducted from the amount allowable under the Foundation Program so that it has no additional effect.) In addition, each district may supplement educational revenues received under the Program with property tax revenues. The practical result is that the state provides about 50 percent of the statewide funds for public education, local districts supply 40 percent from property taxes, and the federal government supplies 10 percent.

The different amounts of taxable property in school districts may lead to substantial interdistrict disparities in school expenditures, despite the fact that property-poor districts 
however, declined to follow the trend of decisions begun by Serrano. The majority opinion, written by Justice Powell, first considers whether a suspect classification is involved: ${ }^{38}$ more specifically, whether the Texas system discriminates against people whose income is below some identifiable level of poverty, against those who are poorer than others, or against those who happen to live in property-poor school districts irrespective of personal income. The opinion notes that, as a matter of fact, neither of the first two types of discrimination is present in the Texas situation; poor people in Texas do not, in either an absolute or relative sense, generally receive lower educational expenditures. Justice Powell then considers whether the third possible suspect classification, which does exist in the Texas system, has any constitutional warrant under applicable precedents; he claims that the strict test of equal protection review has been applied only where a class was completely unable to pay for a desired benefit and thus deprived of a meaningful opportunity to enjoy that benefit. ${ }^{39} \mathrm{He}$ concludes: "The system of alleged discrimination and the class it defines have none of the traditional indicia of suspectness: the class is not saddled with disabilities, or subjected to such a history of purposeful unequal treatment, or relegated to such a position of political powerlessness as to command extraordinary protection from the majoritarian political process." 40

The opinion then considers whether education is among the fundamental interests that trigger application of the strict standard of equal protection review.1 In a morally remarkable discussion, Justice Powell grants the fundamental importance of education but rejects the idea that this fundamental importance is at all relevant to the constitutional question of whether an interest triggers the strict scrutiny test. He contends that importance cannot be the test, because recent Supreme Court decisions have specifically held that burdens on impor-

may have much higher tax rates than property-rich districts. See note 22 supra. On the basis of such disparities, a three-judge district court held the Texas system of educational finance unconstitutional. Rodriguez v. San Antonio Indep. School Dist., 337 F. Supp. 280 (W.D. Tex. 1971). Finding wealth to be a suspect classification and education to be a fundamental interest, the court applied the strict scrutiny test and required Texas to show that the disparities in educational expenditures were necessary to achieve a compelling interest and that this interest was advanced in the way least restrictive of the fundamental interests involved. The Court found that, far from satisfying this stringent test, the Texas financing system could not even satisfy the weak rational basis standard. As the following text indicates, the Supreme Court reversed in a 5-4 decision.

38411 U.S. at 18-29.

39 Id. at 20.

$40 \mathrm{Id}$. at 28.

$41 \mathrm{Id}$. at 29-89. 
tant interests such as welfare benefits and housing are not subject to strict scrutiny. ${ }^{42}$ "Rather, the answer lies in assessing whether there is a right to education explicitly or implicitly guaranteed by the Constitution." 43 Justice Powell then finds that education is neither explicitly nor implicitly guaranteed. He concludes that the causal dependence of intelligent exercise of free speech and voting rights on education does not imply a constitutional guarantee of education, because there was no showing in this case that the system deprived children of "the basic minimal skills necessary for the enjoyment of the rights of speech and of full participation in the political process." 44 Further, he fails to see any way of limiting such a theory in order not to challenge the authority of the recent welfare and housing decisions; people deprived of those goods are, he asserts, equally unable to participate effectively in the political process.

Finally, the majority opinion assesses whether the Texas financing system satisfies the rational basis test. ${ }^{45}$ The Court finds a rational basis for the Texas system in its protection of the autonomy of school districts to decide how and to what extent funds should be spent on education. Justice Powell observes that the Texas legislature may reasonably believe "that along with increased control of the purse strings at the state level will go increased control over local policies."46

The majority opinion recognizes that the Texas financing system is not ideal. ${ }^{47}$ The point is put more succinctly by Justice Stewart when he observes, in a concurring opinion, that the Texas system "can fairly be described as chaotic and unjust." 48 Yet Justice Stewart and the majority failed to find a constitutional defect.

\section{B. The Moral Issue}

Rodriguez raises in acute form the question of the proper relation between moral and legal analysis in constitutional adjudication, for here there is an admitted injustice that the Supreme Court holds constitutionally valid. As noted above, ${ }^{49}$ the relationship between morality and constitutional law is not an exact one. First, the due process and equal protection clauses incorporate a state action requirement that

42 See Lindsey v. Normet, 405 U.S. 56 (1972); Dandridge v. Williams, 397 U.S. 471 (1970). For a discussion of the moral correctness of this point, see text and note at note 130 infra.

43411 U.S. at 33-34.

14 Id. at 37 .

45 Id. at 44-55.

$40 \mathrm{Id}$. at 53.

47 Id. at $15-17,39,44,54-55,58-59$.

$48 \mathrm{Id}$. at 59.

49 See text at notes 4-5 supra. 
renders certain injustices committed by the state, but not by private individuals, subject to constitutional attack. ${ }^{50}$ The appeal of this requirement derives from our firm moral conviction that some areas of people's self-regarding, private lives should not be regulated by the state. The state action requirement goes well beyond this morally defined area, however, excluding from federal constitutional scrutiny many other-regarding actions that are properly regulated by the state, such as private racial discrimination in housing. However unjustifiable the state action requirement may be, it remains a significant barrier to the otherwise natural idea that the due process and equal protection clauses can be used to attack all forms of political immorality.

Judicially imposed restraints on the use of the due process and equal protection clauses further qualify their equivalence to purely moral notions. The concept of what violates equal protection of the laws has been narrowly construed to require that the state must give something in unfair amounts to one class of people over another before the equal protection doctrine will be applied. Thus the equal protection clause does not require that public schools exist, but racial discrimination in existing school services does provide a ground for constitutional objection. ${ }^{51}$ There is no convincing moral justification for the refusal to constitutionalize the right to certain basic services. We must, however, acknowledge that the most morally informed constitutional notions, like due process and equal protection, often require less than purely moral notions.

Moreover, the Court clearly does not regard all forms of state injus-

50 There has been a significant line of cases expanding the notion of state action. E.g., Amalgamated Ford Employees Union Local 590 v. Logan Valley Plaza, 391 U.S. 308 (1968) (peaceful picketing by union in shopping center); Burton v. Wilmington Parking Auth., 365 U.S. 715 (1961) (restaurant leased in publicly owned and operated building); Terry v. Adams, 345 U.S. 461 (1953) (election of candidates to run in Democratic primary); Shelley v. Kraemer, 334 U.S. 1 (1948) (judicial enforcement of racially restrictive covenant); Smith v. Allwright, 321 U.S. 649 (1944) (party primary). It is clear, however, that the line between state and individual action remains. Cf. Lloyd Corp. v. Tanner, 407 U.S. 551 (1972) (there is no dedication of a privately owned shopping center to the public so as to entitle people to exercise first amendment rights therein); Moose Lodge No. $107 \mathrm{v}$. Irvis, 407 U.S. 163 (1972) (the fact that a private club has a liquor license does not constitute state action).

51 "Such an opportunity [education], where the state has undertaken to provide it, is a right which must be made available to all on equal terms." Brown v. Board of Educ., 347 U.S. 483, 493 (1954). In Griffin v. County School Bd., 377 U.S. 218 (1964), however, the Court held that closing the public schools in one county in Virginia, by exercise of local option under state permissive legislation, denied equal protection to the plaintiff Black children; but there was clearly a difference in educational services from county to county. On the general problems raised by Griffin, see Horowitz \& Neitring, Equal Protection Aspects of Inequalities in Public Education and Public Assistance Programs from Place to Place Within a State, 15 U.C.L.A.L. REv. 787 (1968). 
tice as subject to constitutional examination by the judiciary. To be constitutionally scrutinized by the courts, the injustice must be "justiciable"- a "case or controversy" 52 presented in a concrete dispute between adverse parties in a form susceptible to sound judicial examination. Otherwise, no room would be left for the legislature's creative fashioning of just institutions and policies in response to the free and supposedly equal play of political forces, unhampered by the occasional straitjacket of judicial reasoning. In some areas, notably "political questions," even where constitutional provisions clearly apply the courts will abstain from judgment, because other governmental branches are putatively better final judges of the issues involved..$^{53}$ In other cases, for example economic and social legislation, deference to the competence of other branches results in a weak standard of judicial review. ${ }^{54}$

The crucial issue of the appropriate standard for review, whether the courts should apply the strict or weak standard of equal protection review, is raised by cases like Rodriguez. Was this a proper case for judicial deference to legislative wisdom, represented by adoption of the rational basis test, or did this case require the stringent judicial protection against legislative apathy accorded certain basic civil rights and freedoms, thus calling for use of the strict scrutiny test?

\section{The Pringiples of Justice}

The proper analysis of this question turns on the moral force and place of the concept of opportunity among other familiar distributive goods like liberty, life, health, property, and wealth.

An examination of the ordinary language use of the word "opportunity" will clarify the moral notion of opportunity that is central to this analysis. An opportunity, in the ordinary language sense, is a kind of good. An oncoming disaster is generally not considered to be an opportunity, unless one regards it as affording a spiritual exercise or a test of one's mettle. An opportunity, however, is a special kind of good. In general, an opportunity for a person $A$ to do $X$ is said or thought to exist only where some circumstance external to $A$ exists, the presence of which provides a chance of doing $X$. Thus, it is not normally proper to speak of the internal capacities of $A$ that enable him to do $X$ as being opportunities to do $X .{ }^{55}$ Internal endowmentsincluding attitudes, motivations, personality, and beliefs, as well as

62 This requirement is derived from U.S. CoNsT. art. III, $\S 2$.

53 See Baker v. Carr, 369 U.S. 186, 217 (1962); Luther v. Borden, 49 U.S. (7 How.) 1 (1849).

64 See, e.g., Railway Express Agency v. New York, 336 U.S. 106 (1949).

$55 C f$. J. Feinberg, Sociar Philosophy 13 (1973). 
capacities-are at least as significant as external circumstances in explaining why certain good-producing actions occur or are likely to occur, but these endowments are not identified by the normal concept of opportunity.

An opportunity for $A$ to do $X$ is thus an external circumstance that confers a chance or availability of doing $X$ that leads or is believed by the speaker-thinker to lead to some good. A New Yorker may be described as having a certain cultural opportunity, because New York City offers a range of institutions that confer an availability of cultivating and pleasurably exercising cultural sensibilities, the cultivation and exercise of which are, or at least are believed to be, human goods.

The existence of an opportunity does not conclude the question of fair access to that opportunity. A person in prison in New York has no access to that city's cultural opportunities. Access would be similarly impaired by a lack of sensory capacities. If a person were blind, he could hardly appreciate the formal beauties of Balanchine's choreography at the New York City Ballet; if he were deaf, the musical excitement of hearing the New York Philharmonic under Boulez would be unavailable. Poverty might make access to the Metropolitan Opera impossible. Further, if not in prison, not sensorily defective, and not poor, a lack of experience and cultural training might also limit access to New York's cultural opportunities.

The moral concept of opportunity is the type of external chance that is naturally thought of in discussions of the general goods involved in fundamental distributive questions. "General goods" are those things that are typically the objects of people's rational choices and desires, no matter how their more particular ends may be described. ${ }^{58}$ In considering basic distributive questions, one seeks to identify things that are general goods in this sense, that is, describable as being the generalized means to a person's particular ends. It is thus natural to classify liberty as one of these goods; liberty for $A$ to do $X$ implies the absence of constraints, including coercion to do or not to do $X$. By contrast, the mature and reasonable man whose actions are specifically constrained by others in certain directions lacks an essential ingredient of deciding on and pursuing his individual happiness. Liberties of thought (speech, press, religion, and association), civic liberties (the right to vote and participate in political institutions), and freedom of physical, economic, and social movement are among

56 The notion of rationality considered here is developed in D. RICHARDS, A THEORY of Reasons for Action chs. 3,5 (1971). See also C. Fried, An Anatomy of Values ch. VI (1970); J. RAWts, A THEORY OF JUSTICE 407-16 (1971). The general view of the good is discussed in $i d$. at ch. VII; D. RICHARDS, supra, at 286-91. 
the liberties that are in this way fundamental. Such liberties are indispensable to the formation of a self-respect based on full expression of the spirit, self-direction, security of the person, and the possibility of unhampered movement. ${ }^{57}$

Similarly, it is natural to identify capacity, property, and wealth as basic distributive goods. Capacity, the physical, intellectual, and emotional competences necessary to rational action, is obviously a general means that enables people to pursue individual ends. Property, the possessions over which one has legally protected exclusive control and right of disposition, is in some form ${ }^{58}$ a significant means enabling people to pursue their individual and disparate ends. ${ }^{59}$ Wealth, including a medium of exchange, provides the wherewithal to pursue the ends one desires.

In a discussion of such basic distributive goods, it is natural to regard a notion of basic opportunity as also being of fundamental moral importance. Thus, one thinks of a broad class of external circumstances that facilitate full development and expression of the capacities involved in a rational life and that afford unrestricted access to available goods. These opportunities include the family opportunity that a child has for emotional nurture, guidance, and training; the educational opportunity that a child has for training in basic skills; broad cultural opportunity; and the opportunity to take fair advantage of the liberties formally available. The existence of these opportunities, as in the New York example, obviously does not resolve the question of fair access to the good life; opportunity is only one among the general distributive goods. Opportunities of this basic nature are important preconditions to realization of the full value of available liberties. Voting rights are meaningless in a society whose population is

57 Self-respect has its natural basis in our desire to exercise our capacities competently. See D. RICHARDs, supra note 56, at 257, 267-68; White, Ego and Reality in Psychoanalytic Theory: a Proposal Regarding Independent Ego Energies, Psychological Issues (1963), especially ch. 7. The liberties discussed above relate to certain fundamental capacities (for example using language with facility, or autonomously and intelligently planning one's life in terms of actual desires), the competent exercise of which is often the indispensable means to securing other ends. The development of such competences is thus eminently rational; and the liberties that facilitate their exercise and development is a general good. See D. Richards, supra note 56, at 265-66.

58 The notion that property is a general good obviously does not prejudge the morality of private or public ownership of the basic means of production.

59 This category includes the capacity to enter into love and friendship relations whose possibility depends on the special intimacy afforded by being able to waive property rights as to one person but not another. This point seems to underlie the critique of communist systems in ARISTOTLE, Politics, Book II, chs. 3, 4. A similar point is well made regarding privacy in C. FRIED, supra note 56. 
illiterate. Freedom of thought is useless without the training that forms an independent intellectual conscience. Freedom of social and economic movement is without value if institutions do not provide the training to make such movement more probable.

After one attains an understanding of the general distributive goods, questions naturally arise concerning principles to regulate their distribution. The answers to these questions require formulation of the principles of justice. This need for principles of justice arises because of conflicting claims on a limited supply of general goods; some set of clear principles is required to regulate the adjudication of claims on these goods. If there were a superabundance of general goods, or if people were not limited in the extent to which they are willing to sacrifice their interests for the interests of others, the need for principles of justice might be nonexistent or significantly different. ${ }^{60}$

To determine the most acceptable set of principles of justice from the viewpoint of political morality, it is necessary to elaborate a theory of morality that incorporates important features of the intuitive notion of morality, yet enables us to use that notion in determinate and constructive ways. The central features of intuitive moral ideas seem to be notions of treating others as you would like to be treated in comparable circumstances (reciprocity), ${ }^{61}$ judging the morality of principles by the consequences of their universal application (universalization), ${ }^{62}$ ignoring the moral irrelevancies of clan, caste, ethnicity, color, and the like as a basis for judgment, and minimizing fortuitous human differences as a basis for differential treatment. ${ }^{63}$ These formulations are not intended to articulate precisely an analysis of moral concepts, but any plausible analysis must give expression to these intuitive ideas.

The following analysis, derived from the seminal work of John Rawls, ${ }^{64}$ is employed in this article: Moral principles are analyzed in

60 This point was developed by David Hume in his remarkable discussion of the conditions of moderate scarcity. D. Hume, A TREatise OF Human NATURE 485, 495 (1888).

61 Cf. K. BaIER, The Moral PoInt of VIEW ch. VIII (1958); J. Rawls, supra note 56, at 130-32. Similar discussions of the conditions for moral judgments are presented in $D$. Gauthier, Practical Reasoning (1963); G. Grice, The Grounds of Moral Judgment (1967); D. RICHARDs, supra note 56, at ch. VI.

62 Cf. R. HARe, Frefdom and REASON 92-94 (1963); D. Richards, supra note 56, at 83$85,216$.

63 This idea is behind Kant's theory of autonomy. See I. KANT, Foundatrons of THE METAPHYSICS OF MoRALs 65-71 (L. Beck transl. 1959). Mill remarked that the highest justice is "redressing the inequalities and wrongs of nature." $2 \mathrm{~J}$. MuL, Principles of Pormicar Economy 398 (1883). Mill thus concludes that primogeniture is unjust in that it rewards accident. Id. at 505. Henry Sidgwick has contended that justice can reward only voluntary effort and not natural ability. Id. at 505-06, 530 .

64 J. RAwLs, supra note 56. 
terms of the concept of those principles that perfectly rational men, consisting of all people irrespective of historical or actual age, in a hypothetical position of equal liberty and in the absence of any knowledge of who they are specifically but having all other knowledge and reasonable belief, would agree to on the hypothesis that those principles are to be the ultimate standards of conduct that are generally accepted and acted on as the final arbiters of conduct. Reciprocity is incorporated by the idea that moral principles are by definition those that all men would consent to as the ways in which they, as well as others, should be treated in comparable circumstances. Universalization is expressed by the idea that the morality of principles is to be judged on the assumption that they are generally accepted and acted on. The irrelevancy of caste, race, and the like, is guaranteed by ignorance of specific identity; the minimization of fortuitousness is similarly assured.

In the present context the concern is to apply this definition to the circumstances of justice. We introduce into the original position the concept of the general distributive goods and further facts regarding the scarcity of such goods, the conflicting claims thereon, and the specific need for a set of principles to regulate such claims. The account also focuses on a static model of a moral ideal in a relatively economically advanced country, thus eliminating the moral problems of transition.

Given the formal definition of morality, however, a rational strategy of choice in the original position must be defined for the analysis to yield substantive results. The members of the original position cannot predict the probabilities of ending up in a given station of life. It is crucial to appreciate at this point the consequences of deciding on the principles of justice. The principles define a just claim for such basic general goods as liberty, opportunity, wealth, and the like. If a person agrees to principles that permit deprivation of liberty and property rights, he will have no recourse against exploitation that might render his entire life prospects narrow, meager, and bitterly servile. To forestall such crippling consequences, the rational strategy in choosing the basic principles of justice would be the conservative maximin strategy: one chooses the ultimate standards that secure the highest lowest in life prospects from the viewpoint of the original position. Thus, if a person is born into the worst possible station of life allowed by these principles, he or she will be better off than in the worst station allowed by other possible principles.

In considering how to apply the maximin criterion in the original position, it is important to decide which general goods are most funda- 
mental. Inequalities in the distributive shares of these goods are unlikely to secure the highest lowest; the person or class with the least amounts of them would be disadvantaged to a greater extent than by disparities in other goods. The notions of liberty and opportunity seem in that way to be more fundamental than other notions; the question of capacity is explicitly put aside. ${ }^{65}$

It is not difficult to support the view that liberty and opportunity justly have a strong grip on our moral imaginations. A society where the liberties of thought are trammeled is one in which the basic need for expression of the spirit is frustrated, resulting in the distorting rigidities of defined orthodoxies. A society without any voting rights is one in which people's sense of autonomous self-direction shrivels into apathy. ${ }^{66} \mathrm{~A}$ society that does not have equal access to the criminal and civil law provides no security of the person. And a nation that restricts the liberty of physical, social, and economic movement condemns each person to the fortuitous place, social class, and job of his birth, thus reducing horizons and prospects to a nullity and making effort and aspiration stupid because they are in vain. In short, all these liberties facilitate and nurture a basic sense of self-respect, a belief in the competence and integrity of one's person, without which satisfaction of needs is only an escapist refuge from an inner death. ${ }^{67}$

Similarly, certain opportunities are at least as basic. Although a society that does not accord such family opportunities as early emotional nurture, guidance, and training and educational opportunities for training in basic skills may make the various mentioned liberties available, it offers only the form of freedom without realizing its underlying value. ${ }^{68}$

65 The notion of capacity should probably be included with liberty and opportunity. To keep this article on its avowed focus, however, the just treatment of the general capacity problem must be put aside. For a discussion of this point, see D. RicharDs, supra note 56, at 135-38. The moral artificiality thus introduced should be kept in mind, for the existence of unequal capacities raises as many moral problems as unequal liberty or opportunity.

68 The validity of this position is unaffected by possible justifications-ignorance, illiteracy, economic underdevelopment-for the lack of voting rights. A different question is whether universal voting rights with different weights may be justified. See J. RAwLs, supra note 56 , at $231-34$.

67 Rawls regards self-respect as a primary good. Id. at 440-46.

$68 \mathrm{It}$ is no accident that voting rights do not exist as anything more than a plebiscitary sham, if at all, in a society whose population remains illiterate. In such circumstances voting rights may be a form of exploitation rather than a means of liberation. Freedom of thought has no value in the absence of a disciplined training that enables precise, intelligent, and plausible expression of an independent intellectual conscience. Freedom of social and economic movement has little value if institutions do not provide the train- 
In matters involving the fundamental factors that shape a person's capacity to become a full rational being and to enjoy the life of such a being, the rational contractors of our model of political morality could not, consistently with maximin, agree to any principle except equality. Such a principle inherently requires the existence of institutions enabling the most disadvantaged people to have a higher rational expectation of desire satisfaction than any alternative principle. Use of the maximin strategy in choosing institutions relating to liberty and opportunity thus tends to eliminate the disadvantaged class; the highest lowest is equality for all persons.

By contrast, once a certain minimum level of property and income is guaranteed, the rational interest in property and income is not as fundamental as that in liberty and opportunity. Assuming the greatest amount of equal liberty and opportunity ${ }^{69}$ for all, inequalities in the distributed amounts of property and income above the minimum are tolerable if there are countervailing advantages of comparable kind. A relatively poor person, with full liberty and opportunity, may be better off in a system that allows inequalities in the distribution of wealth than in a system requiring equality: the effects of inequality may make him less poor over his life than if there were a mandated equality of wealth.70

The following principles of justice regulating the distributive shares of general goods would therefore be accepted in the original position: ${ }^{71}$

The principle of equal liberty and opportunity. Basic institutions are to be arranged so that every person in the institution is guaranteed the greatest equal liberty and opportunity compatible with a like liberty and opportunity for all.

The principle of justified inequality. Inequalities in the distribu-

ing that makes such movement more probable. And civic liberty, like voting rights, lacks value where people do not have the fair opportunity to make use of it.

69 Including, of course, the liberty and opportunity to hold and dispose of property.

70 For example, incentive effects that prompt the more highly gifted to work more will in a reasonable time increase the quality or quantity of property or wealth available to others.

71 This formulation is taken from D. Richards, supra note 56, at 121. For Rawls's formulation, see J. RAwLs, supra note 56, at 302-03. Rawls's account differs from my formulation in stopping short of my emphasis on the priority of opportunity to the goods governed by the principle of justified inequality; Rawls emphasizes the traditional liberal idea of equal opportunity as access to careers being predicated on talent. See id. at 301, 511-12. I find no defense for Rawls's view other than the intuition that it would subject certain institutions (the family, for example) to extreme criticism, presumably on the ground that the unregulated family distributes opportunities unequally (such as the opportunity to have had more loving or concerned parents). 
tion by institutions of general goods like money, property, and status are to be allowed only if those inequalities are a necessary incentive to elicit the exercise of superior capacities, and only if the exercise of those capacities advances the interests of typical people in all standard classes in the institution and makes the life expectation of desire satisfaction of the typical person in the least advantaged class as high as possible.

The principle of equal liberty and opportunity applies to three types of basic institutions: (a) the legal system, (b) the educational, cultural, and family system, and (c) the economic system of jobs. The legal system is required to guarantee by law the equal right of all persons to the liberties of thought and speech, civic liberties, political liberties, and freedom of physical movement. In the second category equal opportunity requires these institutions to allow children and young adults an equal opportunity to develop their sensitivities and capacities, particularly their rational concept of their welfare in terms of developing and realizing a coherent life plan. ${ }^{72}$ In the economic system of jobs people are to have an equal opportunity to be selected for any job as long as their qualifications are equal. If the second principle applies, so that different social and economic classes justifiably exist, then every person is to have equal liberty and opportunity of movement within the class system consistent with his capacities. ${ }^{73}$

This concept of opportunity must be distinguished from the notion of achievement, a related but not similarly morally fundamental notion. The moral concept of opportunity expresses the idea that people are equally entitled to whatever facilitates their development as rational persons. That a person may be more abundantly endowed with capacities, and thus have higher potential achievement, is irrelevant to this notion; that one may in some sense achieve more with a certain basic opportunity than another person is similarly irrelevant. Unlike achievement, opportunity is governed by a principle of equality, not only because it makes liberties valuable, but also because it is a

72 See commentaries cited at note 56 supra.

73 In thus interpreting the requirements of the first principle of justice, the construction of the liberties and opportunities to which the principle applies avoids the otherwise natural issue of conflicts between certain liberties and opportunities. For example, the omission from the enumerated liberties of parental liberty to educate their children privately avoids the problem that a society according parents this liberty may guarantee more equal liberty than a society that does not, but it also secures a less equal opportunity. This result is intentional; the selection of the types of liberties and opportunities refiects a judgment on the relative weights of various types of liberties and opportunities as general goods. The judgment is made here that the liberty to bring up one's child freely is not on a par with the interests of children in equal opportunity. 
condition of a rational life in which a coherent development of desire and capacity is possible.

\section{Justice and Constitutional Adjudication}

With the above formulation of the relationship between the principles of justice and the allocation of the general distributive goods, the next task is to apply the formulation to define the proper judicial standards for review of legislation bearing on the distribution of these goods. This issue is merely a part of the general question of just constitutional design, and for this purpose we may consider the application of the principles of justice at different stages. ${ }^{74}$ Suppose that rational contractors, after deciding on the general principles of justice, assume another role-delegates to a constitutional convention who, within the constraints of these principles, are to design the constitutional system, the framework within which political forces will operate. The veil of ignorance in the original position is lifted to allow the delegates to know something about the society in which they are located, such as the degree of economic development and educational levels. They do not know, however, who they are in the society. They will therefore have no basis on which to prefer one interest group over another. ${ }^{75}$ This hypothetical idealization is intended to clarify a normative concept: a process or its result is just only to the extent that the process or result satisfies the ideal conditions.

In the United States, with its considerable resources, advanced economic growth, and high literacy, there is probably no single solution to the problem of just constitutional design, but rather a range of constitutions. A form of constitution that seems to be a reasonable solution is the type of constitutional structure currently found in this country-a democratically elected legislature and executive with separate powers, limited by constraints that render fundamental civil and human rights legally immune from political bargaining. Assuming the existence of a trained judiciary independent of the other branches and possessing a special technique by which to interpret and enforce the fundamental civil rights, a certain amount of judicial supremacy in interpreting and enforcing the fundamental civil rights is also justifiable. The problem here is defining the proper limits and role of judicial supremacy.

74 See J. Rawrs, supra note 56, at 195-201.

75 We can similarly consider the questions of just legislation and just administration by imagining the contractors to be legislators, administrators, or judges within the previously fixed constraints. 
The notion of judicial supremacy in the United States has always been intended as a bulwark, as Alexander Hamilton put it, against "encroachments and oppressions of the representative body"76 and "serious oppressions of the minor party in the community." 77 The due process and equal protection clauses of the fourteenth amendment represent an extension of this policy to state governments; the courts of the United States, both federal and state, are to ensure that certain rights are protected from legislative interference by the states. Part of the courts' task in this regard is to determine, as a matter of progressively unfolding constitutional interpretation, the proper standards under which their responsibility is to be discharged.

The injustice of a law, however, should not be deemed sufficient for the state or federal courts to invalidate that law under the due process or equal protection clause. If the courts were used to attack all unjust laws, pressure on the courts for legislative change would become the rule rather than the exception, a mark of weakness in supposedly democratic institutions; judges would become the arbiters of complex social and economic issues that they are ill suited to decide; and the power to govern would shift from elected representatives to an appointed judiciary. Despite this prospect, there is no doubt that a strong judiciary can perform an invaluable function in remedying fundamental injustices that majoritarian rule is unable or unlikely to correct. ${ }^{78}$ The problem is to articulate a clear rule defining the circumstances in which judicial remedies should be available to correct injustices.

The strict standard of equal protection review has generally been applied in cases involving such strong substantive principles of equality that deviations from equality are rarely morally justified. Since $1944^{79}$ the Court has not held any classification or action infringing an interest that triggers the strict scrutiny test to be justified by a compelling state interest. The criminal procedure cases raise the question of fair access to the criminal law system, for the central claim is that indigent defendants, because of financial requirements to obtain transcripts $^{80}$ or legal counsel, ${ }^{81}$ are not allowed an equal chance to enjoy

76 ThE FEDERALIsT No. 78, at 462 (C. Rossiter ed. 1961) (A. Hamilton).

77 Id. at 469.

78 Thus, the Supreme Court has rejected the notion that the availability of initiative and referendum provided sufficient redress to prevent adjudication of an apportionment problem; majority vote could not be trusted to remedy a constitutional violation. Lucas v. Colorado, 377 U.S. 713, 736-37 (1964).

79 Korematsu v. United States, 323 U.S. 214 (1944) (order relocating citizens of Japanese descent from the West Coast to detention camps upheld as constitutional).

80 Griffin v. Illinois, 351 U.S. 12 (1956).

81 Douglas v. California, 372 U.S. 353 (1963). 
their civil liberties. In the voting rights cases, quite minimal poll taxes $^{82}$ have been struck down on the ground that they unfairly burden both the indigent and nonindigent in the exercise of political liberties; schemes weighting votes by geographical location have been held invalid because they dilute and undermine the formally available equality of voting rights. ${ }^{83}$ Residence requirements for the enjoyment of governmental benefits or the exercise of rights have been found to restrict exercise of the right to travel to the extent that the opportunities for enjoying the right of movement are unfairly blunted. ${ }^{84}$ It is interesting to note that none of these examples involve state practices that directly infringe a liberty, and the liberties in question remain formally intact. Rather, the value of the liberties in question or the fair opportunity to make use of those liberties is at stake. ${ }^{85}$

These cases reflect some of the limiting criteria of judicial supremacy that represent the working out by the Supreme Court of the problem of just constitutional design in the United States. The criteria used in equal protection cases seem to be that the courts can intervene to invalidate legislation only where: (1) an injustice involves a violation of strong substantive equality principles from which deviation is rarely justified; (2) the injustice reflects a majoritarian legislative incapacity and unwillingness to act on the claims of justice, not likely to be remedied other than by judicial action; and (3) a reasonably simple and informative standard of reform can be formulated.

These criteria would probably be agreed to by our hypothetical constitutional convention delegates as part of the solution to the problem of just constitutional design. The criteria correctly call for judicial intervention in circumstances in which claims of injustice are peculiarly immune to the remedies of majoritarian rule. ${ }^{88}$ Further, forms of in-

82 Harper v. Virginia Bd. of Elections, 383 U.S. 663 (1966) (poll tax of $\$ 1.50$ held unconstitutional). See also Dunn v. Blumstein, 405 U.S. 330 (1972) (Tennessee requirement that voting be restricted to citizens who have lived in the state for one year and in a county for three months held unconstitutional); Carrington v. Rash, 380 U.S. 89 (1964) (Texas statute excluding military personnel stationed in Texas from voting held unconstitutional).

83 E.g., Reynolds v. Sims, 377 U.S. 533 (1964).

84 E.g., Shapiro v. Thompson, 394 U.S. 618 (1969). See also Dunn v. Blumstein, 405 U.S. 330 (1972).

85 There are some exceptions to this rule. Skinner v. Oklahoma, 316 U.S. 535 (1942), involving the right to procreate, raised the issue of direct coercion in the form of sterilization and thus involved the violation of a liberty. The right to marry was directly denied by the antimiscegenation statutes. See Loving v. Virginia, 388 U.S. I (1967). In Brown v. Board of Education, 347 U.S. 483 (1954), liberty to attend schools was directly restricted. The strict scrutiny cases, however, generally involve the Court's concern not only with liberty, but also with the circumstances that make the exercise of the liberty available and thus valuable.

86 For example, where the interests of systematically isolated minorities, not capable-of the usual forms of political bargaining among interest groups, are involved. 
justice that the courts may remedy are especially appropriate for judicial scrutiny, being violations of strong substantive equality principles. These criteria are certainly not an exhaustive definition of the conditions of proper judicial intervention on constitutional grounds; they are sufficient, not necessary, conditions thereof.

\section{The Constitutionality of School Finanging}

It should now be possible to apply the moral theory and legal analysis developed above to the moral issue raised in Rodriguez. The nature of the complaint in that case was somewhat different from the strict scrutiny cases described above; in Rodriguez there was no contention that any of the independently identifiable liberties of those cases were directly infringed. Most of the strict scrutiny cases invoked elements of the opportunity notion, however, indicating that a moral and legal analysis moving from these cases to the facts of Rodriguez involves movement along a continuum and not a qualitative jump.

An examination of the interests that the Court in the equal protection cases has found so fundamental that it has imposed a stringent criterion of validity indicates that there is no justifiable distinction between the liberties involved in those cases and the pure concept of opportunity centrally involved in Rodriguez. In terms of the fundamental quality of the interest, the opportunity involved in Rodriguez is even more fundamental than the liberties that those cases justly hold inestimable. Although it is possible for a man with full opportunity but without these liberties to flourish, even if by a retreat into spiritual autarchy, a free man without opportunity is often a grosteque and shriveled caricature of the gracious, humane, and abundant self that might have developed if given the appropriate opportunities. Indeed, many Americans never vote, never defend themselves against criminal prosecution, never travel, and yet are happily fulfilled because they have had full opportunity. Further, the effects of deprivations in liberty are often remedied once those liberties are granted, but the effects of deprivations in opportunity are often irremediable.

The case for equal opportunity is particularly strong in a democratic society committed to a constitutional regime based on a community of autonomous consciences, rather than a unity of plebiscitary selfdenial. The equal liberties central to constitutional politics lose their moral roots as an expression of the equality of persons if those liberties are only a sham of equality beneath which lie inequalities in opportunity. The pursuit of all ends requires the appropriate development of capabilities; unequal opportunity leads to unequal development in 
these capabilities, and thus affects the practical use that liberties afford in achieving our ends. Equal liberty without equal opportunity is a pointless charade, a value rendered valueless by apathy, waste, and selfdisgust. Liberty as a condition of self-respect presupposes opportunity.

The issue in Rodriguez was thus whether the method of educational financing violated equal opportunity without justification. The financing of public schools is of course only part of the problem of equal opportunity. Equal opportunity encompasses the entire range of social institutions that relate to the formation of a person's concept of his rational good and his capacity to bring that concept to realization. ${ }^{87}$ This general truth regarding the wide moral application of the opportunity notion, however, does not make the question of educational financing any less important in the discussion of equal opportunity. There is little question that the quality of educational training available in public schools in the United States is a crucial determinant of the degree to which people have the opportunity to develop a rational concept of their own good and the capacity to bring it to realization.

Although the quality of public education is importantly related to equal opportunity, the amount of money expended is arguably not significant. The Coleman Report's ${ }^{88}$ most striking finding was that family background and interaction factors are more basic than amounts of educational expenditures, leading to the conclusion that techniques such as busing may be more useful in combatting the scars of exclusivity patterns than any amount of expenditures on disadvantaged schools. The Goleman Report and subsequent studies of the same and related data, ${ }^{89}$ contrary to the ill-conceived conclusion of some, ${ }^{90}$ do not support the proposition that expenditures bear no relation to opportunity; they merely provide some reason to believe that other factors are more decisive. ${ }^{91}$ Such studies are evidence that large amounts

87 A more narrow concept of opportunity, such as the idea that it only makes careers open to talent, corresponds to no moral justification that can withstand scrutiny. It fails to assess the wide range of opportunities subject to human control that, absent moral regulation, can relatively advantage and disadvantage people without any basis in merit or worthiness.

88 J. Coleman, Equality of Educational Opportunity (1966).

89 The best compilation of later studies is ON EQuality OF EDUCATHonal Opportuniry (F. Mosteller \& D. Moynihan eds. 1972) [hereinafter cited as Mosteller \& Moynihan]. A useful summary of some of these developments is presented in Schoettle, The Equal Protection Clause in Public Education, 71 Corum. L. REv. 1355, 1378-88 (1971). An interesting presentation and interpretation of this data is C. JENCKs, INEQUALITY-A REASSESSMENT OF THE EFFECT OF FAMILY AND SCHOOLING IN AMERICA (1972).

90 See Schoettle, supra note 89, at 1387-88. A more balanced view appears in Overlan, An Equal Chance to Learn, THE New RePublic, May 13, 1972, at 19.

o1 Cf. Hanushek \& Kain, On the Value of Equality of Educational Opportunity as a 
of money spent on education can, given other factors, be only marginally effective in mitigating inequalities of educational opportunity. A marginal effect is still some effect, however, and expenditures do have some force. Indeed, Coleman has noted that his study may have underestimated input effects by failing to distinguish general inputs from specific inputs experienced by children, ${ }^{92}$ and he has also supported the constitutional attack on school financing. ${ }^{93}$

Further, these studies rely on a narrow concept of relative achievement-linguistic skills. ${ }^{94}$ There is no evidence that a more general definition of individual development is not significantly related to expenditures. The moral notion of equal opportunity is quite generally conceived; it rests on the idea of facilitating conditions for rational development, including not only minimal verbal skills but also people's nonverbal capacities. ${ }^{95}$ From the moral point of view it is thus inappropriate to use linguistic skills as the sole test of relative opportunity, although they are part of such a test. Indeed, achievement data is an inexact measure of opportunities afforded, failing to capture the crucial moral difference between achievement and opportunity; equal opportunity does not conceptually or factually imply equal results or achievement. To suppose that the failure to insure equal results is a moral criticism of the pursuit of equal opportunity ${ }^{96}$ is to confuse quite distinguishable moral goals. Thus, there is no convincing moral force in

Guide to Public Safety, in Mosteller \& Moynihan, supra note 89, at 116 (denying the value of the Coleman Report for any policy purpose).

92 J. Coleman, supra note 88, at 150-51. See also Smith, Equality of Education Opportunity: The Basic Findings Reconsidered, in Mosteller \& Moynihan, supra note 89, at 296, 314.

93 See Coleman, Foreword to Coons, Clune \& Sugarman, supra note 23; cf. the view that educational resources affect quality in the short run, though not in the long run, in C. JENCRs, supra note 89 , at 24 .

94 A healthy skepticism about the achievement indices appears in Mosteller \& Moynihan, supra note 89. Consider the fears of extending a "general test-score mania." Id. at 47,5455. See also Armor, School and Family Effects on Black and White Achievement: A Reexamination of USOE Data, in Mosteller \& Moynihan, supra note 89, at 168; Dyer, Some Thoughts About Future Studies, in Mosteller \& Moynihan, supra note 89, at 384. At times, however, certain commentators absurdly relate their achievement indices to variables tested. Jencks notes that music teachers have little effect on achievement as measured, as if music training would be properly measured in verbal ways. C. JENCKs, supra note 89 , at 98 ; cf. Smith, supra note 92 , at $292,314-15$, on the inappropriateness of using verbal achievement data to measure effects of science laboratories and guidance counsellors.

95 See Dyer, supra note 94, at 516-17. A similar point regarding the relation of equal opportunity to diverse ends is made in Campbell, Defining and Attaining Equal Educational Opportunity in a Pluralistic Society, 26 VAND. L. REv. 461, 465 ff. (1973).

96 This is the central thesis in C. JENcrs, supra note 89, at 209-65. Putting aside this regrettable confusion, Jencks's general egalitarian thesis-that the present degree of wealth inequalities in the United States is unjustified-is plausible and quite possibly true. 
the relevant studies, because they do not speak to the proposition that the amount of expenditures significantly affects relative opportunity.

In addition, even if differences in expenditures do not affect relative opportunity, such differences may still act as a crippling stigma in that the child on whom less money is spent perceives a diminished concern and faith in his aspirations and worth. ${ }^{.7}$ Further, if school expenditures are a morally arbitrary factor, then it is unfair to allow some communities excessively to indulge their tastes for making such expenditures. The scarce public resources should either be distributed equally or used where they rationally advance some legitimate policy goal.

It would of course be unreasonable to disregard the evidentiary force that properly may be given the Coleman Report and subsequent studies. They indicate that meaningful efforts toward equal opportunity will require painful reforms in social exclusivity patterns and the like to make effective concomitant reforms in the financing structure. Moral considerations thus indicate that a balanced program of constitutional and legislative reforms should be sought. The school financing issue has its own moral force, however, and may be assessed independent of other needed reforms.

Realizing that educational spending represents a criterion of basic opportunity, the question remains how the principle of equal opportunity applies to such spending. The relationship between equal opportunity and educational expenditures is not simple; equal opportunity does not necessarily entail equal educational expenditures. Unequal expenditures are justified by special handicaps of children, whether a physical disability like blindness or the manifold psychological and physical disabilities resulting from morally significant social deprivation; equal opportunity here may mean that ensuring such children an equal chance of realizing their good requires greater expenditure for them than for other children. The cost of purchasing comparable educational resources also varies from place to place because of differences in the cost of living, school transportation outlays, economies of scale, and the like. It is therefore reasonable to allow for unequal expenditures that correspond to differences in real costs. Indeed, equal opportunity requires such inequalities. In general, it is a reasonable moral position that the principle of equal opportunity requires equal expenditures at the basic educational level, at least through

97 In the separate but equal era, school boards sometimes argued that this effect was avoided because Black schools had some courses, like bricklaying, not available in White schools. E.g., Carter v. School Bd., 182 F.2d 531, 534 (4th Cir. 1950). See also Karst, supra note 34 , at 749-52. 
the mandatory ages of school attendance, unless special handicap or cost levels indicate that equality of opportunity requires inequality of expenditures. ${ }^{98}$

Despite differing levels of natural capacity during the mandatory education period, it is not certain, absent significant disability, that roughly equal expenditures are not needed to give each child an equal chance to develop a rational concept of his or her good and the capacity to achieve it. This uncertainty is increased by the inadequacies in our ability to measure natural capacity at this age. ${ }^{99}$ Due to the absence of rational grounds for different treatment, equality in expenditures is the natural solution. ${ }^{100}$

In addition, some plausible moral arguments support the thesis of equal expenditures. People are variously endowed with natural capacity, but equal opportunity does not require that more resources be spent in developing greater capacities than are spent on the less gifted. To suppose that equal opportunity requires this pattern of spending confuses equal opportunity, premised on fairness to all people, with a notion of exploiting talent for the public good, governed by the principle of justified inequality, or maximizing performance from limited inputs. ${ }^{101}$ Equal opportunity requires equal distribution of the condi-

98 This view allows for possible constitutional attacks on compensatory justice grounds, in contrast to the reluctance of Coons, Clune, and Sugarman to recognize the constitutional validity of compensatory justice claims and their relegation of such claims to solely legislative remedies. See Coons, Clune \& Sugarman, Educational Opportunity, supra note 23, at 341-42, 385. They fail to comprehend the important sense in which compensatory justice is based on an equality principle. For views that compensatory educational justice may properly give rise to constitutional questions, see Horowitz, supra note 23, at 1166-72, and A. WISE, supra note 23, at 183-84.

99 The difficulties in measuring natural endowment, as opposed to effects of environmental and social training, are enormous. That standardized scholastic tests do not accurately make this measurement was the basis for holding the District of Columbia tracking system unconstitutional. Hobson v. Hansen, 269 F. Supp. 401, 473-85 (D.D.C. 1967), aff'd sub nom., Smuck v. Hobson, 408 F.2d 175 (D.C. Gir. 1969); cf. Smith, supra note 92 , at $290-97$.

100 This analysis is not intended to suggest that the means of advancing equal op. portunity are necessarily uniform; choices among diverse ways of spending educational funds may depend on the varying capacities of children. In our present system, however, there is considerable uniformity in education at the mandatory attendance stage. The basic skills to be imparted are similar (reading, writing, arithmetic, hygiene, physical coordination) with variations playing a minor role, in contrast to later education where specialization becomes necessary. The basis for the early uniformity is that in the early stages of life, with later capacities and aptitudes yet unknown, it is rational to provide a sufficiently wide education so as not to inhibit later development of special aptitudes. See D. Richards, supra note 56, at 29-30. This early uniformity supports the appropriateness of equal expenditures at this stage.

101 This distinction is made in article 26(1) of The Universal Declaration of Human Rights in The Right to Be Educated 231 (R. Drinan ed. 1968). See also Grisez, The 
tions facilitating development of capacity; it is therefore doubtful that the more gifted should receive more resources. On the contrary, their superior ability might allow them to develop fully with less external training or resources. It is also morally plausible that lower capacity levels call for higher inputs to remedy, in the short run, the disadvantages of inferior gifts. ${ }^{102}$ This question, however, will not be pursued here as it relates to capacity distribution issues that have been explicitly set aside.

A final moral argument supporting equal expenditures rests on the symbolic importance of equal treatment at this stage in the moral development of children. Development of the capacity to understand the moral equality of people, and to ignore morally arbitrary differences, is hindered by inequalities in expenditure that children naturally perceive as differential assessments of basic moral worth. Yet there is nothing morally more important in elementary education than to foster a sense of fundamental moral equality. Once early education has ensured equal opportunity, however, it can be appropriate for some young adults to receive a college education (by way of subsidy, if necessary) while others do not, at least to the extent that this different treatment advances the common good pursuant to the principle of justified inequality.

The facts of Rodriguez seem to present a clear violation of equal opportunity. The disparate expenditures in the Texas school financing system are not related in any systematic, rational way to adjustments for handicaps, differences in cost levels, or a history of relative deprivation, and thus are not in the nature of those inequalities that might, if anything would, be justified under the principle of equal opportunity. The Texas system, and similar systems in other states, should be unequivocally condemned as a violation of equal opportunity. It might be argued that the system's structure suggests a correlation of educational expenditures with the wealth of parents. ${ }^{103}$ If the Texas system does correlate the wealth of parents with public school expenditures, it is a fortiori condemned. There are reasons of justice why certain

Right to be Educated-Philosophical Reflections in THE RIGHT TO BE EDUaATED 52, 59 (R. Drinan ed. 1968).

102 These views are confirmed in A. WISE, supra note 23, at 155-201.

103 Such a correlation does not necessarily exist in this scheme since school districts with poorer parents might, for example, have high amounts of taxable commercial property; indeed, there is evidence showing little interdistrict correlation between low taxable wealth and poverty. The Supreme Court noted this fact in Rodriguez. 411 U.S. at 23. See Goldstein, Interdistrict Inequalities in School Financing: A Critical Analysis of Serrano v. Priest and Its Progeny, 120 U. PA. L. REv. 504, 522-27 (1972). But see Rodriguez v. San Antonio Indep. School Dist., 337 F. Supp. 280, 281-82 (W.D. Tex. 1971). 
people may be advantaged over other people, such as the principle of justified inequality, but at least in matters involving basic opportunities, ${ }^{104}$ there is no reason for the just deserts of parents to extend to their children. A child is not morally deserving merely because his or her parents are morally deserving. The principle of justified inequality may support a slight advantage to the children of deserving parents, ${ }^{105}$ because the incentives that this principle contemplates may involve the good that parents do with their money for their children. Such advantages must be distinguished, however, from the degree to which parents are currently allowed unjustly to advantage their children through the laws of testamentary disposition and inter vivos gifts, the existence of private schools, the financing of public schools, and the like. This moral point is not altered if the correlation is only between taxable wealth of districts and expenditures on children's education, and not between personal wealth and school expenditures.

The moral issue is easily stated in more general terms than the relatively narrow issue of public school financing. This narrowness, however, should not be allowed to disturb one's sense of the moral focus that school financing provides for this issue. The state is here implicated at a crucial stage in a failure to provide equal opportunity that fundamentally warps children's capacity to understand and realize the nature of a fulfilled and civilized life.

Having identified a clear violation of a strong principle of justice requiring equality in the distribution of a general good on a par with liberty, the other criteria for justifiable judicial intervention developed above $^{106}$ must also be satisfied. The criterion of a majoritarian incapacity and unwillingness to act on the claims of justice is satisfied, because the usual forces of political bargaining are paralyzed for two reasons. First, children, the group primarily affected, lack the right or capacity to vote, and thus their interests lack independent representation. ${ }^{107}$ In addition, the possibility of reform by means of parental representation is typically blocked, with high wealth districts preferring the status quo,

104 Some expenditures are de minimis and thus morally insignificant, being essentially harmless self-regarding consumption by parents.

105 For example, a moderate amount might be given to each child cumulatively over life. See J. Meade, Effictency Equality and the OWNership of Property 54-58 (1964); $1 \mathrm{~J}$. Mill, Principles of Polttical Economy 289-91 (1864).

106 See text and notes at notes 74-86 supra.

107 The only representation is the distorted parental representation. In cases in which parental judgment conflicts with state policy, courts have suggested that the child be asked whether he shares the parental view. See Wisconsin v. Yoder, 406 U.S. 205, 244-46 (1972) (Douglas, J., dissenting); In re Green, 448 Pa. 338, 292 A.2d 387 (1972) (sixteen year old boy should be consulted about blood transfusion that his mother, a Jehovah's Witness, refused to allow). 
average wealth districts neutral, and the property-poor districts left as an ineffective political minority. ${ }^{108}$

The final criterion is reasonable simplicity in the standard of legislative reform. Although no standard with the simplicity of "one person, one vote" seems to be available, two reasonably simple and informative standards can be formulated: "each child, equal resources" and "the quality of public education is not to be a function of wealth other than the total wealth of the state."

The equal expenditure criterion is morally more fundamental, but the qualifications it requires to remain morally acceptable, such as adjustments for handicapped children, make its ease of application subject to doubt. This doubt is baseless, however, in light of past judicial experience with comparable equal opportunity questions. Courts in the United States have never had any difficulty assessing whether forms of educational resource allocation disadvantaged students in unconstitutional ways. In the era before Brown $v$. Board of Education, ${ }^{108}$ when courts judged the constitutionality of racially segregated facilities according to the separate but equal standard, ${ }^{110}$ the United States Supreme Court ${ }^{111}$ and lower federal courts ${ }^{112}$ frequently made such assessments. ${ }^{113}$ Similar assessments have also been made in the postBrown era. ${ }^{114}$ It is simply not true that courts are unable to assess questions of educational opportunity in a rationally defensible way. They have done so in the past and, given an adequate constitutional theory, can do so in the future.

108 Similar points are made in Coons, Clune \& Sugarman, Educational Opportunity, supra note 23, at 324-27, 414. A. WISE, supra note 23, at 198, suggests that legislative inertia in the education area is more extreme than in the reapportionment area; the former involves legislators' protection of their constituents', as well as their own, interests.

109347 U.S. 483 (1954).

110 See Plessy v. Ferguson, 163 U.S. 537 (1896). See also Gong Lum v. Rice, 275 U.S. 78 (1927).

111 See, e.g., Mclaurin v. Oklahoma State Regents, 339 U.S. 637 (1950); Sweatt v. Painter, 339 U.S. 629 (1950); Missouri ex rel. Gaines v. Canada, 305 U.S. 337 (1938).

112 See, e.g., Carter v. School Bd., 182 F.2d 531 (4th Cir. 1950); Davis v. County School Bd., 103 F. Supp. 337 (E.D. Va. 1952); Butler v. Wilemon, 86 F. Supp. 397 (N.D. Tex. 1949); Pitts v. Board of Trustees, 84 F. Supp. 975 (E.D. Ark. 1949); Freeman v. County School Bd., 82 F. Supp. 167 (E.D. Va. 1948).

113 See generally A. Wise, supra note 23; Euston, Constitutional Law: Equal Quality in Educational Opportunities-The Necessary Revolution, 40 U.M.K.C.L. REv. 185, 196-99 (1971-2); Horowitz, supra note 23, at 1149-50.

114 See, e.g., Rogers v. Paul, 382 U.S. 198 (1965) (existing inequalities are such that gradually integrating grades only one a year does not suffice); Hobson v. Hansen, 269 F. Supp. 401, 496-97 (D.D.C. 1967), aff'd sub nom., Smuck v. Hobson, 408 F.2d 175 (D.C. Cir. 1969); In re Skipwith, 14 Misc. 2d 325, 180 N.Y.S.2d 852 (Dom. Rel. Ct. 1958) (violation of equal protection where fewer licensed teachers assigned to Black and Puerto Rican schools). 
It is submitted that such a constitutional theory exists and that an equal expenditure criterion, with practical accommodations, is not an unmanageable judicial standard. Courts might sensibly employ a variation of the maximum variance ratio criterion used in reapportionment cases, ${ }^{115}$ so that the maximum variation in average expenditure per pupil could be no more than, for example, two to one. The precise ratio chosen would be determined by considering price level differences, economies of scale, and the like. Such a formulation could give rise to a presumption of constitutionally unjustifiable inequality of opportunity, rebuttable only in well-defined cases. ${ }^{116}$

The criterion that educational quality is not to be a function of wealth other than the total wealth of the state, adopted in Serrano, ${ }^{117}$ may be more easily applied than the equal expenditure criterion, but it leaves the range of legislative remedies morally overbroad. ${ }^{118}$ It is a defensible moral position, however, that the appropriate standard for the purposes of judicial formulation, application, and review should be different from the more intricate standard that the legislature properly should apply in response to the judicial mandate. 119 The consequence of this view, however, is simply to postpone the formulation of a morally more sensitive standard until the legislature enacts a scheme compatible with Serrano but not with equal opportunity. There is thus little reason not to impose the morally finer standard in the first instance.

All the reasons prompting the application of the strict scrutiny test in the cases noted above are as strong, if not more so, in a pattern of school financing of the type presented in Rodriguez. The extension of this test to Rodriguez would have'been consistent with the moral and legal rationale of those cases.

\section{A CRItique of the Majority OpInION in Rodriguez}

Judged against the foregoing moral and legal analysis, the majority opinion in Rodriguez fails to provide satisfactory legal or moral justifi-

115 See generally A. Wise, supra note 23, at 156-57, 201.

116 A similar view was presented in Fiss, Racial Imbalance in the Public Schools, 78 HARv. L. REv. 564, 588-98 (1965).

$1175 \mathrm{Cal} .3 \mathrm{~d}$ at $610-15,487 \mathrm{P} .2 \mathrm{~d}$ at 1259-63, $96 \mathrm{Cal}$. Rptr. at 619-23. The criterion was formulated in Coons, CuUNe \& Sugarman, supra note 23, at 303-04 ("Proposition I").

118 In conformity with this possible judicial mandate, a legislature could retain property taxes but reapportion educational finance districts so that all districts had the same taxable wealth; it could retain the present districting but regulate the permissible rates for different districts so that district wealth would become a neutral factor; it could discard the present system altogether and go to a system of centralized state financing from income taxes; and so on.

118 Cf. A. Wise, supra note 23, at 146-47, 158-59. But see id. at 201, where Wise suggests a preference for the equal expenditure criterion even for judicial purposes. 
cations for its result. Its assertion that the strict scrutiny cases always involve absolute, not relative, deprivation of a benefit ${ }^{120}$ ignores significant prior case law. As Justice Marshall notes in his eloquent dissent, ${ }^{121}$ the view that the strict scrutiny test is based on this notion is inconsistent with holding a poll tax of $\$ 1.50$ invalid in toto although the discrimination extended only to a small portion of the electorate; ${ }^{122}$ and also with the criminal procedure cases in which there was no question of the right to appeal, but rather of the adequacy of that right when transcripts or counsel are not financially available to the poor to better effectuate the right. ${ }^{123}$ Further, in the racial discrimination $^{124}$ and reapportionment ${ }^{125}$ cases, the issue typically was not whether a benefit or a right was given, but whether that benefit or right, once given, was afforded on terms of substantive equality. This general line of cases is thus based on the broad proposition that when certain interests, regulated by principles requiring substantive equality, are present, the courts may intervene to guarantee that equality.

A similar misunderstanding of the moral basis of the strict scrutiny cases is reflected in the majority opinion's insistence that the Court could not hold education to be a fundamental interest requiring the application of the strict scrutiny test ${ }^{126}$ without reconsidering its recent findings that welfare benefits and housing are not fundamental interests. ${ }^{127}$ Subsistence may be as basic as liberty and opportunity, but significant distinctions between these values still exist for constitutional purposes, at least where a general subsistence minimum is ensured. Liberty and opportunity are governed by an equality principle, but questions of personal wealth and the like are governed by the principle of justified inequality. Although this article does not defend

120411 U.S. at 20.

$121 I d$. at $118-20$.

122 Harper v. Virginia Bd. of Elections, 383 U.S. 663 (1966).

123 Douglas v. California, 372 U.S. 353 (1963); Griffin v. Illinois, 851 U.S. 12 (1951).

124 Brown v. Board of Educ., 347 U.S. 483 (1954); see note 17 supra.

125 Reynolds v. Sims, 377 U.S. 533 (1964); Baker v. Carr, 369 U.S. 186 (1962).

126411 U.S. at 37.

127 In Dandridge v. Williams, 397 U.S. 471 (1970), the Court upheld under the rational basis standard a Maryland statute establishing a maximum amount of welfare aid a family can collect regardless of the number of children in the family. Dandridge did not expressly deny that subsistence was a fundamental interest. Rather, welfare legislation, when not involving other freedoms such as the right to travel, is not subject to the strict scrutiny test because it is a "state regulation in the social and economic field." 397 U.S. at 484 . Similarly, in validating a provision in the California constitution requiring that proposals to construct federally financed low-income housing be approved by local referenda, the Supreme Court did not consider whether the affected housing interest was fundamental. James v. Valtierra, 402 U.S. 137 (1971); cf. Lindsey v. Normet, 405 U.S. 56 (1972) (procedural limitations imposed on tenants by the Oregon Forcible Entry and Wrongful Detainer Law upheld under the rational basis test). 
either the position that gross deprivations in wealth-related goods can never properly be the subject of constitutional attack, ${ }^{128}$ or the position that the present distribution of wealth and property in the United States is just, it is submitted that the distribution of wealth-related goods would not properly be morally or constitutionally assessed under the strict scrutiny test, except where such goods are distributed in clear violation of equal liberties ${ }^{129}$ or where the distribution of such goods bears on the question of equal opportunity. Absent such cases, it is not morally correct that the unequal distribution of wealth-related goods is always presumptively unjust. Rather, it is morally correct to assert that the failure to provide certain minimum amounts of such goods can be unjust. Thus, the strict scrutiny test-rooted in equality principles-is not the proper constitutional test. Instead, if such matters are properly reviewed on constitutional grounds at all, the due process clause-rooted in notions of a moral minimum-is the proper constitutional ground upon which to assess distributions of these goods. ${ }^{130}$

In addition, it must be remembered that the values of self-determination and self-respect to which liberties give expression presuppose the opportunity to develop a vision of one's rational good and the capacities to achieve this good. Therefore, to provide judicial protection for equal liberty while denying such protection, where necessary, to equal opportunities frustrates the moral ends that liberty and opportunity together affirm. This peculiarly close connection between liberty and opportunity necessitates similar constitutional treatment.

The analysis in the majority opinion is thus fundamentally defective. As Justice Marshall notes, ${ }^{131}$ the Constitution does not expressly guarantee the right to procreate, the right to vote in state elections, or the right to an appeal from a criminal conviction, yet the Court has protected these interests with strict equal protection review, supposedly because of their significant relation to other clear constitutional rights. It is submitted that the Court was also affected by their relation to

128 The unfortunate suggestion that we may ignore these problems is in Coons, Clune, \&: Sugarman, Educational Opportunity, supra note 23 , at $386-87$, and has been justly attacked in Karst, supra note 34, at 725-29.

129 See, e.g., Hawkins v. Town of Shaw, 437 F.2d 1286 (5th Cir. 1971) (racial discrimination in Mississippi city's provision of street paving and lighting, sewers, watermains, drainage, and fire hydrants violates the equal protection clause).

130 Cf. Michelman, Foreword: On Protecting the Poor Through the Fourteenth Amendment, 83 HARv. L. Rev. 7 (1969). Michelman, mistakenly in my opinion, tries to analyze educational financing in terms of a moral minimum notion that he takes to underlie the strict scrutiny test. See text at note 157 infra.

131411 U.S. at 100. 
strong substantive principles of equality. Recognizing education as a fundamental interest is compatible with such an analysis. The majority opinion begs the question when it uses the lack of evidence that the financing system deprives people of minimal political skills to negate the connection between education and these civil rights. That a fundamental interest is not completely ignored is not a defense to a claim of unconstitutional deprivation of that interest. That people are given some voting rights does not establish the constitutionality of weighting voting rights by geographical location. ${ }^{132}$ Since free speech and voting are clearly constitutionally protected fundamental interests, the concern should be about inequalities in educational opportunity that affect the equal exercise of these rights. To regard educational minima as the proper standard incorrectly assumes that only minimal conditions for the exercise of free speech and voting rights are constitutionally relevant. The Court fails to recognize the moral force of opportunity as a general good on a par with liberty, and similarly regulated by a principle of substantive equality.

Further, the claim that education is related to effectuating guaranteed political and civil liberties in the same way as welfare benefits or housing is unjustified. It is surely a tenable position that educational and cultural disabilities can make people far more vulnerable and politically ineffective than any other factor. ${ }^{133}$ Lack of adequate housing or income does not render people politically ineffective, unless it is combined with such deprivations in opportunity as make movement in the class system impossible and the exercise of political and civil liberties unintelligent or apathetic. Yet the majority opinion naively ignores this factual, and traditionally American, connection between liberty and opportunity. ${ }^{134}$

Omission of relevant considerations is also found in the majority's failure to find that the class of people in property-poor districts is in "such a position of political powerlessness as to command extraordinary protection from the majoritarian political process"135 and thus is not subjected to a suspect classification. This conclusion ignores the crucial fact in Rodriguez: the Texas school financing system disadvantaged children who had no independent political representation and whose parents were an ineffective political minority. The claims of injustice raised in the case are not answered by saying, as the majority

132 Reynolds v. Sims, 377 U.S. 533 (1964).

133 This position was confirmed for me when I spent four months on special assginment from my law firm to a poverty law office on the West Side of Manhattan.

134 See generally 2 A. DE TOCQueVILLE, DeMocracy IN AMERICA (1945).

135411 U.S. at 28. 
opinion does, ${ }^{136}$ that the present system is at least less unjust than the previous system. ${ }^{137}$

The majority opinion also tries to support its holding with references to the Coleman Report and subsequent studies that claim to show that educational expenditures have only a marginal effect on educational opportunity as measured by certain achievement indices. Aside from the question of whether these studies bear on the question of equal opportunity at all, ${ }^{138}$ it is paradoxical that studies primarily directed at showing that equal opportunity turns on deeper social variables than educational expenditure alone should now be used to deny the relevance of educational expenditures altogether. Christopher Jencks, a primary mover in developing these studies, flatly rejects such a view, arguing that education as a benefit reflected in expenditures should be equitably distributed, even ignoring the long-term effects of education. ${ }^{139}$

Finally, one cannot ignore the effect of the above analysis on the majority opinion's conclusion that the Texas system has a rational basis in that it allows local school districts to determine the level of educational expenditures. In fact this position is false to the extent that property-poor districts are severely prejudiced in their capacity to set a level of educational expenditures comparable to that of property-rich districts. In addition, as the following analysis of possible financing schemes indicates, the notion of local control in this context is generally morally suspect.

\section{The Proper Direction of Legislative Reform}

This article has presented a moral and constitutional argument criticizing the basis and holding of Rodriguez and, by implication, supporting the result in. Serrano and its progeny. Despite Rodriguez, the Serrano line of cases is still very much alive; state courts continue to strike down systems of school financing on state constitutional

136411 U.S. at 39.

137 In this connection, the Court cites Katzenbach v. Morgan, 384 U.S. 641 (1966). Citation of Katzenbach is not responsive; that case involved a practice that was assumed to be not independently unconstitutional, but that the legislature could nonetheless regulate in order to promote constitutional values. Rodriguez, however, involves a practice that is directly under constitutional challenge.

138 See text and notes at notes 88-105 supra.

139 C. JENCKs, supra note 89 , at 22-23. Even Daniel Moynihan does not argue against more equal distribution of educational resources, but only against greater total expenditure. See Moynihan, Equalizing Education-In Whose Benefit?, Puв. INTEREsT, Fall, 1972, at 87-89. 
grounds. ${ }^{140}$ The question of the proper direction of legislative reform must therefore be faced.

Serrano does not articulate any sense of what constitutes a "just" method of educational financing, but rather defines the politically unjust. The opinion states that a certain system of financing education does not satisfy constitutional requirements, but the standard of legislative reform it adopts leaves open the question of what remedies the legislature should develop. Serrano is also ambiguous about the moral interpretation underlying the choice of remedies. This absence of moral analysis of the legislative question has led some commentators to suggest reforms that are as defective as the systems considered in Serrano and Rodriguez.

Coons, Clune, and Sugarman's remarkable and admirable book, Private Wealth and Public Education, ${ }^{141}$ presents a plausible method of constitutional attack on the state school financing schemes, which succeeded in Serrano and its progeny, but the legislative reform it suggests as a solution to the problem is disappointing. In their proposal, called "power equalizing,"142 the legislature would define a standard district and a standard rate of taxation-for example, District $X$ with $\$ 1,000$ taxable wealth and a 1 percent tax rate yielding $\$ 10$ revenue. If District $Y$, with a taxable wealth of $\$ 100$, raised $\$ 1$ with a 1 percent tax rate, it would receive $\$ 9$ from the state's general tax revenues. If District $Z$ had $\$ 2,000$ taxable wealth and taxed at 1 percent, it would be required to contribute the excess $\$ 10$ to the state; thus, property-rich districts are likely to tax at a rate below the standard. School expenditures would therefore not exceed those of the standard district chosen in each state. The authors claim that this scheme cures inequality of opportunity and preserves the value of local control; that is, it allows districts to set the level of school expenditures, but it frees the choice from the contingencies of district wealth.

This legislative solution, however, merely substitutes an inequality based on the accident of a district's willingness to tax to raise revenues for education for the condemned inequality based on the accidents of the district wealth. The authors state that "[i]f poor districts tax lower than [the standard] percentage rate because their voters do not care as much about education as those in other districts, under the rules of power equalizing they deserve less and get less: the system

140 Robinson v. Cahill, 62 N.J. 473, 303 A.2d 273 (1973).

141 CoONs, Clune \& Sugarman, supra note 23.

142 Id. at ch. 6. 
is working properly." 143 This proposition is condemned by any reasonable understanding of equality of opportunity, which rests not on the moral merits or demerits of parents but on the rights of children as moral persons. Beneath a wealth of sophisticated sociological and legal analysis, there is a crude moral confusion between the justice of differential rewards (governed by the principle of justified inequality) and the separate question of the justice of differential educational advantages for children (governed by the principle of equal opportunity). ${ }^{144}$

This error is caused by the authors' attempt to shift the focus of the moral examination of school financing systems from the real issue - unjustified inequalities in school expenditure-to a concern that is not similarly morally fundamental-the disproportionate sacrifice required in a property-poor district to raise the same amount of revenue as a property-rich district. The latter prospect may be unjust, but its unfairness arises from the general injustice of a regressive tax on capital wealth and not the specific injustice in educational expenditures present in Serrano and Rodriguez. This confusion has led some commentators to regard the Serrano opinion merely as a response to unjust taxation ${ }^{145}$ or improperly weighted voting rights. ${ }^{146}$ This interpretation is mistaken, as shown by considering that if the unjust taxation aspect were removed, the injustice of unequal opportunity might remain acute. ${ }^{147}$

This shift in emphasis from equal opportunity to unjust taxation derives from a concern that the value of local control be preserved; power

143 Id. at $213,224$.

144 In general, Coons, Clune, and Sugarman seem to be aware that children should be innocent of the deserts of their parents. Id. at 242; Coons, Clune \& Sugarman, Educational opportunity, supra note 23, at 390-95. They fail to make the connection, however, between this view and their power equalizing proposal. It is possible that the authors adopted this stand for reasons of judicial success. Cf. Lawyer's Committee for Civil Rights Under Law, School Finance Litigation: A Strategy Session, 2 Yale Rev. LAw \& Soc. Action 149, 163-64 (1971). At the oral argument in Serrano, plaintiffs' counsel specifically rejected a requirement of equal spending over geographical areas, thus securing, in the opinion of one commentator, more votes for their position. See Karst, supra note 34, at 738-39.

145 Goldstein, supra note 103, at 527-34; Karst, supra note 34, at 736-39.

146 The voting rights analogy is carried to an extreme in Schoettle, supra note 89, at $1401-12$.

147 It should also have been clear that this interpretation was constitutionally unprofitable. The United States Supreme Court has repeatedly refused to consider equal protection objections to comparable unjust taxation claims. See, e.g., MacKay Tel. \& Cable Co. v. Little Rock, 250 U.S. 94 (1919); Sunday Lake Iron Co. v. Township of Wakefield, 247 U.S. 350 (1918); cf. W. Blum \& H. Kalven, The Uneasy Case for Progressive TaxaTION 6-11 (1953). It is thus not surprising that the Court in Rodriguez, to support its finding of constitutionality, should view the case essentially as an attack on the discriminatory effects of a tax scheme. 411 U.S. at 27. 
equalizing allows local control over the rate at which districts will tax to finance education. This concern for local control was also voiced by the majority in Rodriguez in its rational basis examination. Local control would not be a defensible value, however, if it meant local control of the allocation of voting rights, free speech, equal access to the criminal and civil law, and the like. The rhetoric of local control is a moral harlequinade when used to remit such basic requirements of justice to the fitful defense of local authorities. It is a sign of our moral immaturity as a people, reflected in the views of commentators and the Supreme Court, that we do not clearly see that it is similarly outrageous to allow the distribution of basic opportunities to depend on local option. The idea of local control has no moral force when confronted with the concept of equal opportunity. Local control is properly exercised only after a financing system is designed that ensures more justice in the distribution of educational resources. Local decision might then have a proper role in deciding how such expenditures are to be used, subject to appropriate minimum state guidelines.

Coons, Clune, and Sugarman also apply their power equalizing suggestion to develop another notion, "family power equalizing," that has been applauded by some commentators ${ }^{148}$ who share the doubts expressed in this article about district power equalizing. This scheme applies a standard percentage to a standard income, yielding a specific amount of money available for children's education. When this percentage is applied to the income of a poorer family, the result is a smaller amount of money than the standard; and the family, assuming it chooses this percentage, will receive a subsidy to make up the difference. Families with income above the standard who spend the standard educational percentage are presumably required to pay any excess over the standard amount to the state.

Family power equalizing could easily be tied into Milton Friedman's stimulating voucher scheme for educational financing. ${ }^{140}$ This controversial suggestion involves granting educational vouchers to families for each child; the vouchers could be used as payment at whatever school the parents choose for their child. The plan would encourage competition among schools to draw students and might also increase the ability of parents to send their children to schools previously not within their range of choice. Family power equalizing introduces into this scheme the concept that grants be allocated to families according to their percentage propensity to spend on educa-

148 See Michelman, supra note 130 , at 53-54.

149 See M. Friedman, Captralism and Freedom ch. VI (1965); Friedman, The Voucher Idea, The N.Y. Trmes MAGaztne, Sept. 23, 1973, at 22 ff. 
tion. ${ }^{150}$ The power to choose any type of school would thus reflect parental preferences for children's education, rather than their relative level of wealth.

The general Friedman scheme has appeal, but only above the level of basic education. ${ }^{151}$ Exclusivity along lines of talent, class, ethnic group, and the like begins soon enough without a system of education that provides maximum expression for such exclusive tendencies. ${ }^{152}$ A society in which different classes of people rarely interact can have no firm basis for moral community. ${ }^{153}$ At the basic educational level, such exclusivity also cripples capacity development. Thus, the case for some type of genuinely common schools up to some minimum age is strong indeed. Although some form of Friedman's scheme might accommodate this objective, ${ }^{154}$ such a scheme might simply be a system of public schools similar to the one we now have.

Whatever attraction one finds in Friedman's scheme, however, is dispelled when it is combined with family power equalizing. Family

150 Coons and Sugarman have developed a detailed legislative scheme, the Family Choice in Education Act, embodying their concept of the correct relation between family power equalizing and the voucher scheme. See Coons \& Sugarman, Family Choice in Education: A Model State System for Vouchers, 59 CaxIF. L. Rev. 321 (1971). Parents would be given the chance to choose to send their children to one of a number of types of schools within busing distance of their homes. Each type would represent a different level of expenditure per pupil above a minimum level; tax assessments would be based on ability to pay so that all classes would incur equal sacrifice in choosing a certain type of school.

151 Friedman seems to acknowledge this fact, but his scheme does not give full weight to the force of this distinction. See M. FRIEDMAN, supra note 149, at 98-100.

152 It is no accident that segregationists turned to voucher schemes, unsuccessfully, after 1954 in an attempt to maintain segregated education. Cf. Poindexter v. Louisiana Financial Assistance Comm'n, 275 F. Supp. 833 (E.D. La. 1967), aff'd, 389 U.S. 571 (1968); Hall v. St. Helena Parish School Bd., 197 F. Supp. 649 (E.D. La. 1961), aff'd, 368 U.S. 515 (1962).

153 Cf. C. Crossland, The Future of Soclalism $165 \mathrm{ff} ., 195$ ff. (1963); R. Tawney, Equality 144-45 (1964). See also Hobson v. Hansen, 269 F. Supp. 401, 419, 504-06 (D.D.G. 1967), aff'd sub nom., Smuck v. Hobson, 408 F.2d I75 (D.C. Cir. 1969).

154 Morally, the most plausible voucher scheme is the regulated compensatory model proposed in Center for the Study of Public Policy, Educational Vouchers: A Report in Financing Elementary Education by Grants to Parents (1970). In this proposal larger vouchers would be given to disadvantaged children to provide an incentive for schools to accept them, with a provision for a lottery to fill half of oversubscribed schools and choice by the school to fill the other half. Even this scheme allows for systematic isolation by ability, as the authors admit. A better structure would involve a system of quotas, which would directly attack the tendency to discriminate that is the central defect of voucher schemes; the authors recognize this possibility, but dismiss it as politically impractical. Id. at 80-84. Their concern in this area, however, leads them to revise their proposal to require that schools accept a percentage of minority students at least equal to their percentage of minority applications. Id. at 173, 270. Although it seems that the scheme allows too much scope to invidiousness, it has been criticized for not allowing enough. Coons \& Sugarman, supra note 150, at 341-44. 
power equalizing introduces the ultimate invidiousness that children are to be discriminated against in receiving educational benefits based on their parents' propensity to spend for their children's education. This system thus expresses the common confusion of advocates of local control: it equates the moral question of the equal opportunity rights of children with the question of the rights of adults freely to choose different levels of consumption, ${ }^{155}$ as if the basic rights of children were merely a form of consumer goods in which parents may properly indulge arbitrary and disparate preferences. It supposes, as do more plausible voucher schemes, ${ }^{156}$ that maximizing parental choice is in itself a value, without introducing the decisive element of children's rights. Once the distinction between the moral basis of equal opportunity and the issue of the deserts of parents becomes clear, family power equalizing, like local control in general, loses its moral plausibility.

The independent moral basis of equal opportunity enables one to understand the natural role of the state in adjudicating fairly among conflicting claims to opportunity, including claims by children who cannot represent themselves. The compulsory education laws arose in part from this view; the laws are clearly paternalistic legislation designed as much to control the fanaticism or selfishness of parents as the whims of children. The state, on grounds of fairness among children, has similarly decided to some extent that schools should have a certain student body composition and that resources should be equalized among children irrespective of parents' wishes. It is submitted that this policy must in both respects be carried still further. If family control and supervision has failed to secure completely equal opportunity, it is because that system favors an invidious vested interest that tramples on children's rights to the fairness in life they deserve as people. A reading of the facts of the school financing cases evidences a failure of the unregulated family to achieve equal opportunity. There is little reason to believe that family power equalizing would systematically correct this situation in a manner that moral justice requires.

What is morally needed is not the assurance of a minimum in educational benefits, but genuine equality. For example, Frank Michelman, in advocating the clarifying power of the moral notion of a distributive minimum in understanding the equal protection cases, fails

165 This confusion is evident in Coons \& Sugarman, supra note 150, at 330, 337. It is an example of the common confusion between rationality and moral reasonableness. See D. RICHARDS, supra note 56, at 75-79.

150 See Center for the Study of PUblic Policy, supra note 154, at 11, 119. 
to see that a moral minimum is not what the education cases involve; this failure leads him to applaud family power equalizing, but not district power equalizing. ${ }^{157}$ That such a notion is not involved in these cases is clear from the fact that the financing plans in Serrano and Rodriguez were attempts to provide minimum educational spending levels. In this context, they cannot be criticized on the grounds that Michelman proposes, but only on the technical ground that the minimum level is insufficient.

Finally, once the real ground of equal opportunity is made clear, the moral failure of the Texas and California systems is more precisely identified; and the form of legislative rectification points in quite a different direction than family or district power equalizing. The morally desirable form of legislative response to Serrano and its progeny is simply equality in expenditures for basic education, with allowances for special handicaps.

\section{Conclusion}

This article has tried to show that the recent Supreme Court school financing decision both is based on defective legal and moral analysis and fails to explain satisfactorily why strict equal protection review should not be extended to education. If one believes in principled and reasoned constitutional adjudication, Rodriguez must be disappointing, for it is not supported by sound constitutional principles or moral or legal reasoning. The majority could not have reached this decision had it given precise thought to the nature and weight of the moral concept of equal opportunity.

At the beginning of this article our common intellectual need to accomplish a satisfying fusion of constitutional and moral theory was noted. Rodriguez reflects our poverty of constitutional and moral theory. This plight, however, is not the responsibility of the Court alone or of lawyers in general, for the confusion implicit in the case also exists in moral and political philosophy ${ }^{188}$ to which judges and

157 Michelman, supra note 130, at 47-59.

158 See F. HAYEK, THE Constitution OF LIBERTY 384-88 (1960). Hayek suggests that, because justified inequalities in educational advantages are not related to moral merit, any inequalities in educational benefits should be tolerated. He thus confuses the considerations underlying the principles of equal opportunity and justified inequality. The confusion is further evidenced by his insistence that an unrestricted pursuit of equal opportunity would lead to the creation of an elite based on merit. Id. at 387-88. Admittedly, if the principle of justified inequality were ruthlessly pursued in the area of education without concern for the principle of equal opportunity, we would have a meritocracy based on profound injustice. See M. Young, THE RISE of THE Merrtocracy (1958). This principle shows, however, that equal opportunity is not worth consistently pursuing, but rather that equal opportunity is independent from inequalities of capacity. 
lawyers have vainly looked for guidance. This deficiency in philosophy is partially the result of a once fashionable philosophical metaethics that, supposing moral language to be entirely subjective, saw no useful connection between moral philosophy and law, with its undoubtedly objective language. ${ }^{159}$ This old view is now under much deserved critical attack, ${ }^{100}$ and its waning may allow revival of a useful interrelation of law and philosophy.

The present article reflects the return to an interrelation of law and philosophy. The argument has tried to demonstrate that a certain moral analysis may clarify the nature and weight of the moral ideal of equal opportunity and that important constitutional and legal questions depend on the moral analysis. This account should be regarded critically both as the faltering beginning of a wider attempt to remedy our common problem, ${ }^{161}$ and as an invitation to similar explorations.

159 The leading recent statements of this metaethics are R. HARE, Frefdom AND REAson (1963); R. Hare, The Language of Morals (1952); C. Stevenson, Ethics and LaNGUAGE (1944). The leading jurisprudential statement of the objectivity of law is H. KELSEN, GENERAL THEORY OF LAW AND STATE (A. Wedberg transl. 1945).

160 A systematic statement of this attack is presented in D. RICHARDs, supra note 56. See also G. Warnock, Contenrporary Moral Philosophy (1967); G. Warnock, The OBJECT OF MORALITY (1971). A suggestive account of the implications of this attack for constitutional adjudication is in Dworkin, Nixon's Jurisprudence, supra note 1.

161 This account can easily be further developed. The considerations adduced above argue against any form of basic educational level private school that tends to become an enclave of exclusivity based on class, race, religion, and the like. We may, however, be beyond the day when any serious constitutional objection to the existence of private lower schools could be entertained. See Pierce v. Society of Sisters, 268 U.S. 510 (1925). See also Wisconsin v. Yoder, 406 U.S. 205 (1972); Meyer v. Nebraska, 262 U.S. 390 (1923). The issue of public aid to private schools, however, remains a lively political and constitutional issue. The arguments developed in this article support an expansive reading of constitutional inhibitions against such aid and provide a reason to resist political moves in that direction. 